Ewa Dybowska

ORCID: https://orcid.org/0000-0002-0454-772X

Akademia Ignatianum w Krakowie

Katarzyna Wojtanowicz

ORCID: https://orcid.org/0000-0001-5082-2617

Uniwersytet Papieski Jana Pawła II w Krakowie

\title{
Superwizja pracy z rodziną - wybrane implikacje
}

\section{Wstęp}

Przemiany współczesnego życia społecznego sprawiają, że zmienia się także rodzina oraz warunki jej funkcjonowania. Dzięki wewnętrznym procesom samoregulacyjnym wiele rodzin radzi sobie z coraz to nowymi wyzwaniami. Osoby podejmujące pracę z rodziną charakteryzują się zaś podejściem familiocentrycznym, czyli takim, które w centrum oddziaływań stawia całą rodzinę nuklearną. Nie ulega już wątpliwości, że każda rodzina posiada swoją indywidualną mądrość i w jej doświadczeniu tej należy szukać zasobów do usprawnienia funkcjonowania rodziny" ${ }^{1}$.

\footnotetext{
$1 \quad$ I. Krasiejko, Rodzina z dziećmi. Rodzina dysfunkcyjna, Warszawa 2019, s. 81.
} 
Celem artykułu jest ukazanie roli i znaczenia superwizji w pracy z rodziną. Wybranym przedmiotem analiz jest wzmacnianie kompetencji w zakresie pracy z rodziną i poszerzania wiedzy o rodzinie, a także coraz pełniejszego rozumienia procesów w niej zachodzących. Superwizja podnosi standard pracy i jej wymiar etyczny. Zrozumienie funkcjonowania rodziny, szczególnie tej o cechach dysfunkcjonalnych, wymaga wszechstronności, a jednym w najważniejszych elementów współpracy z rodziną jest przygotowanie adekwatnego do jej potrzeb planu pomocy. Zastosowane formy i metody pracy z wymagają ewaluacji, którą również wypełnia superwizja. Superwizja wzmacnia również systemowe podejście do rodziny oraz jej podmiotowość. Poddawanie zatem przez specjalistów wspierających rodziny swojej pracy superwizji jest dziś postulowanym standardem.

\section{Superwizja pracy z rodziną}

Praca z rodziną wymaga metodycznego podejścia, doboru odpowiednich środków i narzędzi, prowadzenia monitoringu i ewaluacji. Realizację tego procesu powinna wspierać superwizja. Staje się ona dziś nie tylko przywilejem, a także ważnym elementem profesjonalizacji działań służb pomocy społecznej zajmujących się rodziną, między innymi pracowników socjalnych, asystentów rodziny, streetworkerów, animatorów społeczności lokalnej, koordynatorów pieczy zastępczej, realizatorów procedury Niebieskiej Karty, pracowników DPS-ów, ŚDS-ów, prowadzących WTZ, specjalistów zatrudnionych w świetlicach środowiskowych, CIS-ów, KIS-ów czy realizatorów projektów w obszarze pracy socjalnej.

Superwizja to pojęcie wielowymiarowe, a jej zastosowanie jest szerokie. W polskim systemie pomocy społecznej zaczyna dopiero zyskiwać zaufanie - jesteśmy w fazie jej wdrażania. W zawodach wsparcia społecznego, szczególnie w pracy filantropijnej, superwizja zaczęła się rozwijać już w XIX wie$\mathrm{ku}$, początkowo w organizacjach amerykańskich i angielskich. W XX wieku została zaimplementowana również do pracy socjalnej. Koncepcję superwizji pracy socjalnej, do której dzisiaj się odnosimy, jako pierwszy przedstawił 
Alfred Kadusin², a na polski grunt przeniósł ją Jerzy Szmagalski. Samo pojęcie zostało zaczerpnięte $\mathrm{z}$ angielskiego słowa supervision, które oznacza „nadzór”, „kontrolę”, „kierowanie”. W praktyce pracy socjalnej superwizja odnosi się jednak do czynności konsultacyjno-doradczych, wzmacniających specjalistę i traktuje jako narzędzie profesjonalizacji pracy i przeciwdziałania wypaleniu zawodowemu.

Prawnie „superwizja pracy socjalnej” w Polsce, zgodnie z zapisami art. 121.a ustawy o pomocy społecznej, polega na „ustawicznym rozwoju zawodowym pracowników socjalnych, służącym utrzymaniu wysokiego poziomu świadczonych usług, zachowaniu i wzmacnianiu kompetencji zawodowych, udzielaniu wsparcia, poszukiwaniu źródeł trudności w pracy i możliwości ich pokonywania", a prawo do korzystania z superwizji ma każdy pracownik socjalny ${ }^{3}$. Ustawa nie odnosi się jednak do innych specjalistów pracujących w systemie pomocy społecznej, jednak i w tych pozostałych zakresach znajduje szerokie zastosowanie.

Jak wskazuje Jerzy Szmagalski, superwizja w pracy socjalnej wypełnia trzy funkcje:

- administracyjną polegającą na koordynacji działań pracowników w placówce i ze społecznością (np. współpracy z innymi placówka$\mathrm{mi}$ ), pracy z personelem i kierownictwem nad opracowaniem polityki i procedur wspierających działania placówki,

- edukacyjną - specyficzny rodzaj doskonalenia kadry, w którym szkolenie jest podporządkowane potrzebom danego pracownika pracującego z określonymi przypadkami, napotykającego określone problemy i wymagającego zindywidualizowanego programu edukacyjnego,

- wspierającą, nakierowaną na pomoc w radzeniu sobie przez pracownika ze stresem zawodowym i traumatycznymi incydentami, liczbą i złożonością przypadków składających się na jego obciążenie w pracy ${ }^{4}$.

\footnotetext{
2 A. Kadushis, Supervision in Social Work, New York 1976, za: J. Szmagalski, Superwizja pracy socjalnej. Zastosowania i dylematy, Warszawa 2009, s. 11.

3 Ustawa z dnia 5 sierpnia 2015 r. o zmianie ustawy o pomocy społecznej (Dz. U. z 2015 r. poz. 1310).

$4 \quad$ J. Szmagalski, Superwizja pracy socjalnej. Zastosowania i dylematy, dz. cyt., s. 21-21.
} 
Według Marca Fereiry superwizja zyskała uznanie jako istotna i dynamiczna metoda nauki połączona $\mathrm{z}$ realiami zawodu, stanowiąca niejako pomost pomiędzy teorią i praktyką, służąca do wytyczenia nowych koncepcji oraz praktycznego nauczania. Autor definiuje ją jako proces nauki i rozwoju, w którym superwizor i superwizowany, w kontekście edukacyjnym i wsparcia, aktywnie łączą teorię i praktykę w celu przygotowania pracownika do pracy socjalnej, wzbogacając ją o przemyślenia obydwu stron. Jednym z głównych celów superwizji jest zbudowanie i rozwój tożsamości zawodowej. Superwizja jest wykonywana w celu wytworzenia przestrzeni dla wiedzy zawodowej i dyskusji nad studiami przypadku, które pozwolą na rozwinięcie umiejętności oraz poszerzenie wiedzy pracownika o procesie interwencji. Przestrzeń ta pozwala również na ocenę zadań wykonywanych przez pracowników socjalnych, a tym samym na motywów koncepcyjno-emocjonalnych, które doprowadziły do podjęcia przez niego takich, a nie innych działań ${ }^{5}$.

Jak natomiast wskazuje Aurela Włoch, superwizja może być prowadzona w różnych obszarach pracy socjalnej, ale przede wszystkim w tych, w których pracownik napotyka na różne trudności będące źródłem niepowodzeń w prowadzonej przez niego pracy socjalnej ${ }^{6}$.

Superwizja pracy socjalnej ma więc w szczególności na celu:

- zapewnienie wsparcia pracownikowi socjalnemu w realizacji codziennej pracy socjalnej,

- analizę procesów i relacji zachodzących pomiędzy pracownikiem socjalnym i jego klientem, w szczególności tych o podłożu problemowym (stresogennym),

- zwiększenie świadomości i rozumienia pełnionej roli zawodowej.

Ja ukazuje praktyka, najczęstszym obszarem superwizji w pracy z rodzinami są

- omówienie indywidualnych przypadków,

- analiza diagnozy, problemów, planów pracy i przyjętych strategii,

5 M. Ferreira, Superwizja w pracy socjalnej, w: Superwizja jako instrument rozwoju zawodowego w służbach społecznych, red. M. Ferreira, M. Grewiński, J. Reis-Jorge, Warszawa 2014, s. 30 .

$6 \quad$ A. Włoch, Superwizja w różnych obszarach pracy socjalnej, w: Superwizja pracy socjalnej, red. M. Grewiński, B. Skrzypczak, Warszawa 2014, s. 255.

7 Opracowanie K. Wojtanowicz na przykładzie własnej praktyki prowadzenia superwizji pracy w obszarze wsparcia społecznego. 
- poszerzenie wiedzy i umiejętności pracy z rodzinami/przypadkami,

- monitorowanie codziennej pracy oraz jej ewaluacja,

- uzyskanie wsparcia emocjonalnego oraz większej świadomości pracy $\mathrm{z}$ danym przypadkiem, lepszego rozumienia i odpowiedzi na potrzeby klientów,

- wsparcie edukacyjne w zakresie wdrażania nowych metod i narzędzi pracy socjalnej,

- wypracowanie nowych rozwiązań oraz kooperacja z szerokim gronem partnerów na rzecz danej rodziny,

- analiza własnego podejścia oraz problemów pojawiających się w pracy z daną rodziną,

- rozpoznanie przestrzegania granic kompetencji i stosowanych rozwiązań,

- wzmocnienie zastosowania procedur organizacyjnych lub w przypadku ich braku wypracowanie niezbędnych procedur,

- przeciwdziałanie wypaleniu zawodowemu, w szczególności pomoc w radzeniu sobie ze stresem.

$\mathrm{W}$ codziennej praktyce zawodowej specjaliści pracujący z rodzinami napotykają szereg sytuacji stresogennych, wymagających analizy i superwizji. Do najtrudniejszych można zaliczyć:

- odebranie dziecka z rodziny biologicznej,

- skierowanie na przymusowe leczenie osoby $\mathrm{z}$ zaburzeniami psychicznymi,

- umieszczenie klienta bez jego zgody w domu pomocy społecznej,

- pracę z rodziną dotkniętą przemocą,

- pracę z rodziną lub osobą wykazującą zaburzenia w funkcjonowaniu społecznymi interwencje w celu zmiany sposobu jej funkcjonowania, dostosowanie do tzw. „normy społecznej”,

- brak motywacji klienta do zmiany i brak współpracy,

- opiniowanie sytuacji rodziny oraz wnioskowanie do sądów o wydanie zarządzeń w sprawie rodziny,

- odmowa udzielani pomocy.

Specjalista taki, w swoim poczuciu działający w tzw. „dobrej wierze”, realizując obowiązki w oparciu o normy prawne i społeczne, często mierzy się z refleksjami, które wywołują u niego szereg dylematów natury etycznej. Również podejmowanie interwencji obarczone jest dużym ładunkiem 
emocjonalnym, z którym zazwyczaj musi mierzyć się samodzielnie. Do tego dochodzi ocena jego postępowania ze strony przełożonych, innych służb (np. sądów) i w końcu opinii publicznej, która niejednokrotnie zarzuca takiemu pracownikowi zaniechanie lub błędne działanie. W pokonywaniu tych trudności niezbędna jest właśnie superwizja, której przedmiotem jest stworzenie przestrzeni do omówienia:

- refleksji nad doświadczeniem związanym z pracą,

- emocji,

- odniesienia do teorii,

- wskazania i nabycia nowych umiejętności,

- poszukiwania nowych metod i narządzi interwencji,

- badania wątpliwości związanych z pracą,

- odniesienia do zagadnień etycznych,

- refleksji nad doświadczeniem własnym.

Celem superwizji jest zatem wsparcie oddziaływań pracownika w zakresie skutecznego wykonywania zadań zawodowych, jego umiejętności praktycznych, stosowanych metod i narzędzi pracy oraz wsparcie emocjonalne. Ma się to przełożyć na profesjonalizację procesu pomocowego pracowników systemu wsparcia rodziny.

Ważną kwestię realizacji procesu pomocowego podejmuje José Reis Jorge. Dzieli się on własnymi refleksjami specjalisty realizującego procesy wsparcia. Za O’Donoghue „superwizja jest procesem ułatwiającym krytyczną refleksję czynów, procesów, osób i kontekstu praktyk usług społecznych. Proces ten ma miejsce $\mathrm{w}$ relacji profesjonalnej pomiędzy superwizorem usług społecznych i superwizowanym, co sprzyja ulepszaniu praktyki usług społecznych". Bez poddania pracy z rodziną refleksji, którą daje superwizja, pracownicy są narażenia na ryzyko przeprowadzenia nietrafnej interwencji lub wypracowania nieakceptowanej przez rodzinę ścieżki pomocy. Może to skutkować brakiem pożądanych rezultatów, a w konsekwencji wypaleniem zawodowym pracowników. Wpływa to również na nabieranie dystansu i braku zaufania do systemu pomocy przez klientów.

Również Izabela Krasiejko we wskazówkach merytorycznych dla asystentów rodziny wskazuje na ważność superwizji. Jak podaje autorka, „aby uzyskać pewność w działaniu, nie wystarczy jedynie ukończenie szkoły

8 J. Reis-Jorge, Praktyka refleksji: droga do profesjonalnego rozwoju i autonomii, w: Superwizja jako instrument rozwoju zawodowego w służbach społecznych, dz. cyt., s. 56. 
wyższej lub specjalistycznego kursu i włączenie poznanych treści do praktyki na zasadzie prób i błędów. Należy jeszcze samemu czy przy pomocy doradcy metodycznego lub superwizora uruchomić postawę refleksyjną, mobilizującą do zastanawiania się nad sytuacją i efektami działania"’.

\section{Organizacja i wdrażanie superwizji w pracy z rodziną}

Przed wdrożeniem superwizji w danej jednostce organizacyjnej pomocy społecznej warto, by kierownictwo wraz z pracownikami zastanowiło się nad poniższymi kwestami:

1. Jaki cel i funkcje ma spełniać superwizja?

Warto w zespole zastanowić się nad indywidualnymi potrzebami jego członków, potrzebami klientów oraz instytucji. W ten sposób określa się cele i funkcje, które przybliżają do spełnienia tych potrzeb.

2. W jakiej formie ma być prowadzona superwizja: indywidualnej czy grupowej?

Kluczowym aspektem skuteczności jest wybór liczby uczestników w sesji superwizyjnej. Są pracownicy, którzy preferują pracę w relacji bezpośredniej superwizor-superwizant, gdyż taka relacja daje im największe poczucie bezpieczeństwa. Są też tacy, dla których oprócz superwizora ważny jest również ogląd grupy, jej refleksja, osąd i docenienie. Dla takich pracowników korzystna będzie superwizja grupowa. Warto również stwarzać możliwość uczestnictwa w superwizji grupowej z możliwością udziału w superwizji indywidualnej.

3. Z jaką częstotliwością będzie przeprowadzana superwizja?

Superwizja to proces. Aby mógł on zafunkcjonować, zarówno pomiędzy superwizorem a superwizantem, jak i pomiędzy superwizorem superwizantem a grupą superwizyjna należy zaplanować systematyczność spotkań i odpowiednia liczbę godzin. Najczęściej superwizja indywidualna trwa dwie do trzech godzin, natomiast grupowa (grupy do dwunastu osób) trzy do ośmiu godzin, w częstotliwości co najmniej raz w miesiącu. Proces superwizji opiera się na kontrakcie superwizyjnym zawartym pomiędzy superwizorem

9 I. Krasiejko, Asystentura rodziny. Rekomendacje metodyczne i organizacyjne, Warszawa 2016, s. 42. 
a superwizantem /superwizantami, w którym określone są wszystkie zasady kształtujące jego realizację.

4. Z jakim superwizorem rozpocząć współpracę?

Superwizje pracy socjalnej powinni prowadzić superwizorzy pracy socjalnej. Jest to jednak warunek wymagany do superwizji pracowników socjalnych ${ }^{10}$, natomiast $\mathrm{w}$ pozostałych zakresach przepisy nie precyzują wymagań wobec superwizorów. Warto natomiast pamiętać, że wiedza, umiejętności i doświadczenie superwizora oraz wykorzystanie ich w procesie superwizji przekładają się na powodzenie całego procesu. Superwizor bierze odpowiedzialność za jego organizację i prowadzenie. Osoba taka odgrywa wiele ról: wspierającego doradcy, towarzysza w pokonywaniu trudności i analizie pracy superwizanta, osobistego i grupowego trenera. Istotny jest również styl preferowany w pracy superwizora - do najczęściej stosowanych należą: doradczy, ekspercki, prowadzący, facylitacyjny oraz wspierający. Warto też zwrócić uwagę na preferowane cechy superwizora, m.in.: znajomość problematyki superwizji i bogate doświadczenia w tym zakresie, wysoki poziom umiejętności komunikacyjnych, metod i narzędzi pracy z rodziną. Superwizor powinien być osobą godną zaufania, krytyczną, ale nie krytykującą, o przyjemnym sposobie bycia ${ }^{11}$. Ważne, aby pracownicy mieli udział w wyborze superwizora.

Tak przygotowany proces wdrożenia superwizji w danej jednostce organizacyjnej pomocy społecznej może przełożyć się większą mobilizację pracowników do uczestnictwa w niej oraz budowanie zaufania do jej skuteczności i konieczności stosowania. To zaś przekłada się na realizację złożonych celów oraz wzmocnienie procesu pomocy rodzinie.

\section{Korzyści z poddawania pracy z rodziną superwizji}

Wspieranie procesu zmian oraz rozwoju rodziny jest wyzwaniem dla wszystkich specjalistów. Wymaga on nie tylko wiedzy teoretycznej i umiejętności

\footnotetext{
10 Ustawa z dnia 5 sierpnia 2015 r. o zmianie ustawy o pomocy społecznej (Dz. U. z 2015 r. poz. 1310).

11 P. Domaradzki, J. J. Krzyszkowski, M. Sosnowski, A. Włoch, Superwizja pracy socjalnej dla praktyków, Łódź 2016, s. 31-33.
} 
praktycznych. Istotną rolę odgrywają również kompetencje osobiste specjalisty podejmującego pracę z rodziną oraz organizacja pracy w jednostce specjalizującej się w pomocy rodzinie. Nie bez znaczenia jest również poddawanie pracy z rodziną superwizji. Udział w tym procesie ma wiele korzyści, na które wskazują w badaniach ewaluacyjnych uczestnicy superwizji ${ }^{12}$ :

1. Uczestnicy superwizji wzmocnili swoje kompetencje zawodowe w zakresie:

- diagnozy i etapów metodycznej pracy z rodzinami przeżywającymi trudności,

- dostrzegania roli współpracy interdyscyplinarnej,

- analizy sytuacji rodziny, diagnozowania problemów,

- opracowania strategii pomocy rodzinie,

- stosowania przepisów i procedur,

- stosowania nowych metod i narzędzi pracy z rodzinami,

- identyfikowania własnej roli zawodowej oraz potrzeby i zakresu doskonalenia zawodowego.

2. Uczestnicy superwizji wzmocnili:

- motywację do działania

- kompetencje osobiste w zakresie umiejętności stawiania granic w relacji z klientem, współpracownikami i partnerami, budowania skutecznej współpracy,

- kompetencje społeczne: w obszarze komunikacji, asertywności, rozwiązywania konfliktów, wyrażania swojego zdania,

- umiejętność radzenia sobie z trudnościami w realizacji działań, emocjami i stresem oraz przeciwdziałania wypaleniu zawodowemu, zastosowania technik relaksacji,

- pewność w realizacji codziennych działań oraz świadomość występowania ograniczeń: klientów, własnych i instytucjonalnych,

- umiejętności dostrzegania sukcesów w realizacji działań,

12 Badania ewaluacyjne w zakresie korzyści z uczestnictwa w superwizji czy poddawania jej własnej pracy superwizji prowadzone przez Katarzyna Wojtanowicz w latach 20182019 na zakończenie procesu superwizji w jednostkach organizacyjnych pomocy społecznej prowadzących pracę z rodzinami na mocy Ustawy z dnia 12 marca 2004 r. o pomocy społecznej (Dz. U. 2004 Nr 64 poz. 593 ze zmianami), Ustawy z dnia 9 czerwca 2011 r. o wspieraniu rodziny i systemie pieczy zastępczej (Dz. U. $2011 \mathrm{nr} 149$ poz. 887 ze zmianami) oraz Ustawy z dnia 29 lipca 2005 r. o przeciwdziałaniu przemocy w rodzinie (Dz. U. 2005 nr 180 poz. 1493 ze zmianami). 
- etyczne podejście do realizacji działań zawodowych.

3. Korzyści z zastosowania superwizji dla instytucji:

- doskonalenie organizacji pracy,

- lepsze stosowanie stosowania przepisów prawa, procedur wewnętrznych oraz wypracowanie nowych procedur,

- poprawienie jakości pracy zespołowej i współpracy z innymi partnerami,

- mniej konfliktów w zespole,

- stabilny zespół pracowników,

- wypełnienie standardów i zaleceń kontrolnych,

- wypracowanie nowych rozwiązań,

- wzmocnienie funkcji zarządczej.

\section{Wzmacnianie kompetencji w zakresie funkcjonowania rodziny}

Superwizja jako przestrzeń do wzmacniania kompetencji pracy z rodziną, analizowania jej sytuacji, diagnozowania problemów, a także planowania pracy wymaga aktualizowania i poszerzania wiedzy dotyczącej funkcjonowania rodziny jako środowiska życia. W identyfikacji zakresu i rodzaju koniecznych zmian w toku podejmowanej pracy socjalnej pomocne jest rozumienie oraz uświadamianie sobie procesów zachodzących w codzienności życia rodzinnego. Rodzina bowiem jako środowisko życia, w tym także jako środowisko wychowawczo-socjalizacyjne, może stymulować bądź hamować rozwój jednostki ${ }^{13}$. Znajomość ogólnych prawidłowości dotyczących funkcjonowania rodziny, ich wyjaśnienie i przewidywanie stanowi punkt odniesienia dla planowania pracy socjalnej z rodziną.

Rzeczywistość rodzinna to przede wszystkim system psycho-społeczny charakteryzujący się tylko sobie właściwą społeczną i emocjonalną

13 E. Wysocka, Warsztat diagnostyczny pracownika socjalnego w obszarze pracy $z$ rodzina oraz przedmiotowe i podmiotowe uwarunkowania procesu diagnozy środowiska rodzinnego, w: Pomoc społeczna wobec rodzin. Interdyscyplinarne rozważania o publicznej trosce o dziecko i rodzinę, red. D. Trawkowska, Toruń 2011, s. 201. 
organizacją ${ }^{14}$. Istotne zatem jest rozpoznanie struktury rodziny nuklearnej, wzorców komunikowania się jej członków, a także relacji z instytucjami, osobami czy organizacjami zewnętrznymi wobec niej. Rodzina - środowisko życia - funkcjonuje jako system, tak że jedna osoba w nieunikniony sposób wpływa na wszystkich pozostałych. W związku z tym zachowanie jednostki w środowisku życia rodzinnego nigdy nie może być spostrzegane jednowymiarowo i deterministycznie. W ujęciu tym strukturę rodziny stanowią nie tylko osoby wchodzące w jej skład - należy także uwzględnić funkcjonujące w niej zasady, wymagania, oczekiwania prezentowane przez poszczególnych członków. W tak rozumianą strukturę wchodzą także wszelkiego rodzaju procesy, których istnienie wpływa świadomie lub podświadomie na codzienność poszczególnych jednostek i zachodzące w niej zjawiska ${ }^{15}$. Istotne z perspektywy wsparcia rodziny i jej pomocy, a także towarzyszenia jej w wychodzeniu z sytuacji trudnej lub kryzysowej, jest zwrócenie szczególnej uwagi na relacje pomiędzy jej członkami, które w systemie rodzinnym nie przebiegają linearnie, gdyż wszystkie części tegoż systemu i jego struktura są ze sobą powiązane. Nie można zrozumieć w pełni żadnej osoby w izolacji od reszty systemu rodzinnego. Wyżej zasygnalizowane rozumienie jego struktury zakłada, że funkcjonowania rodziny nie można zrozumieć przez prosty opis jego jednostokowych elementów (osób lub procesów). Struktura i organizacja rodziny silnie wpływają bowiem na zachowanie wszystkich członków systemu i często deterministycznie go określają ${ }^{16}$.

$\mathrm{W}$ takim rozumieniu rodziny nasuwa się pytanie o to, kto odpowiada za cały system rodzinny, kto kształtuje atmosferę życia rodzinnego, a przede wszystkim - kto jest w stanie zapewnić homeostazę systemu rodzinnego. Dla każdego systemu (także rodzinnego) istotne bowiem jest pozostawanie $\mathrm{w}$ dynamicznej równowadze między stałością a zmianą ${ }^{17}$. Zdecydowanie najważniejszy $\mathrm{w}$ danym gospodarstwie domowym jest podsystem małżeński czy też podsystem dorosłych. Są oni - jak określa Virginia Satir

\footnotetext{
14 E. Jarosz, E. Wysocka, Diagnoza psychopedagogiczna: podstawowe problemy $i$ rozwiązania, Warszawa 2006, s. 118.

15 W. Świętochowski, Rodzina w ujęciu systemowym, w: Psychologia rodziny, red. I. Janicka, H. Liberska, Warszawa 2014, s. 26-27; M. de Barbaro, Struktura rodziny, w: Wprowadzenie do systemowego rozumienia rodziny, red. B. de Barbaro, Kraków 1999, s. 45-55.

16 A. Margasiński, Teoria $i$ wybrane modele systemów rodzinnych, w: Rodzina w ujęciu systemowym. Teoria i badania, red. A. Margasiński, Warszawa 2015, s. 7.

17 W. Świętochowski, Rodzina w ujęciu systemowym, dz. cyt., s. 38.
} 
- „architektami rodziny”18. Podsystem dorosłych (podsystem małżeński, relacja partnerska) daje początek rodzinie, a w ujęciu systemowym poczucie zadowolenia lub niezadowolenia małżonków warunkuje funkcjonowanie całego systemu. Życiowe spełnienie małżonków ma swoje odbicie w panującej w rodzinie atmosferze i wpływa na poczucie bezpieczeństwa jej członków. Dzieci są zwykle bystrymi obserwatorami rodziców i funkcjonowania rodziny. Jakość i intensywność komunikacji między małżonkami są przenoszone na relacje z dziećmi, a te w sposób świadomy bądź nieświadomy naśladują rodziców, którzy są dla nich punktem odniesienia do kształtowania dalszych postaw i zachowań. Relacja między małżonkami, partnerami i rodzicami dla dzieci ma charakter prototypowy. Podsystem małżeński określa podział obowiązków i organizację całego życia rodzinnego. Zadowolenie rodziców ze związku sprawia, że organizacja życia rodziny jest harmonijna i daje przestrzeń do rozwoju każdego z jej członków ${ }^{19}$. Brak poczucia satysfakcji czy brak zadowolenia ze związku wprowadza natomiast w system rodzinny znamiona chaosu, niepewności, braku stabilności, a czasami także tzw. parentyfikację, czyli przejmowanie przez dzieci ról dorosłych ${ }^{20}$.

Wydaje się oczywiste, iż podejmując pracę z rodziną, nie wystarczy skierować swojej troski tylko na jednego jej członka. Wszelkie wysiłki i działania wspierające skierowane na wzmocnienie diady rodzicielskiej wzmacniają cały system rodzinny. Rodzina prawidłowo funkcjonująca opiera się na diadzie małżeńskiej, którą tworzą dwie osoby o w miarę dojrzałych osobowościach. Prawidłowe porozumiewanie się rodziców, troska o zaspokojenie potrzeb i o siebie nawzajem dają podstawę do wychowania i opieki nad dziećmi ${ }^{21}$.

Przemiany społeczne oraz ekonomiczne, jakie zaszły i zachodzą w życiu społecznym, spowodowały wiele zmian w strukturze zewnętrznej i wewnętrznej rodziny ${ }^{22}$. Zmiany te powodują, że część rodzin przechodzi kryzys, zanim osiągnie stan wewnętrznej równowagi. Kryzys w rodzinie to

\footnotetext{
18 V. Satir, Terapia rodziny. Teoria i praktyka, Gdańsk 2000, s. 18.

19 W. Świętochowski, Rodzina w ujęciu systemowym, dz. cyt., s. 31-32.

20 T. Rostowska, J. Borchet, Proces parentyfikacji w kontekście teorii systemowej, „Roczniki Pedagogiczne" 44 (2016), t. 8 nr 3, s. 6.

21 M. Ryś, Relacje wewnątrzrodzinne w świetle badań psychologicznych, w: Oblicze współczesnej rodziny polskiej, red. B. Mierzwiński, E. Dybowska, Kraków 2003, s. 34.

22 A. Błasiak, Między (nie)obecnością a zaangażowaniem. Rodzicielstwo rekonstruowane w ponowoczesności, Kraków 2019, s. 89.
} 
zespół okoliczności zewnętrznych i wewnętrznych, które wpływają na rodzinę tak, że w danym systemie zaczynają się i utrwalają zmiany. Ich rezultatem jest zwykle powstanie nowego jakościowo układu lub nowej struktury ${ }^{23}$. Kryzysy, które powodują trwałe zmiany w strukturze systemu rodzinnego, $\mathrm{z}$ jednej strony mają przyczynę w naturalnej dynamice życia rodziny, a z drugiej wywołane są czynnikami osobowymi, a także zewnętrznymi wobec tego systemu. Związane są one z cyklem życia rodzinnego, czyli rodzaju „szkicu historycznego” przebiegu życia rodziny nuklearnej, na który składają się poszczególne etapy - począwszy od narzeczeństwa poprzez pojawianie się dzieci, opuszczanie rodziny przez dorosłe dzieci aż do osiągnięcia wieku emerytalnego przez rodziców ${ }^{24}$. Zmiany w tym cyklu to tzw. kryzysy rozwojowe związane kolejnymi etapami życia. Oprócz jej naturalnego rozwoju kryzysy, które spotykają rodzinę, związane są z nagłą chorobą czy śmiercią, rozwodem, koniecznością zmian funkcjonowania na skutek problemów zdrowotnych czy niepełnosprawności, nagłym spadkiem zasobów finansowych ${ }^{25}$.

Współczesna rodzina stanowi swoistą mozaikę, gdyż obok już istniejących stale przybywają nowe modele życia rodzinnego. Jej codzienność jest więc związana z wyborami różnych stylów życia, form relacyjnego funkcjonowania czy strategii opiekuńczo-wychowawczych. Maria Braun-Gałkowska mówi, że daną grupę osób czy system strukturalny nazywamy rodziną wtedy, gdy jej członków łączą ścisłe więzy i wspólne życie. To właśnie charakter tych więzi oraz ich jakość decydują o satysfakcji z życia rodzinnego i poczuciu spełnienia (lub braku satysfakcji) w tej przestrzeni ${ }^{26}$. Nieustannie dokonujące się przeobrażenia rodziny spowodowały dziś zmiany strukturalne, funkcjonalne i świadomościowe w codzienności rodzinnej. Zmiany te

23 J. Tarnowski, Praca z osobami i rodzinami w sytuacji kryzysowej, w: Rola pracy socjalnej w przeciwdziałaniu zjawisku wykluczenia społecznego, red. D. Błasiak, I. Piątkowska-Lipka, Katowice 2012, s. 163.

24 K. Ostoja-Zawadzka, Cykl życia rodzinnego, w: Wprowadzenie do systemowego rozumienia rodziny, dz. cyt., s. 18-30.

25 E. Lipowicz, Praca socjalna z rodzina. Diagnoza-projektowanie-zmiana, Zielona Góra 2014, s. 54-58.

26 M. Braun-Gałkowska, Psychologia domowa, Lublin 2008, s. 20-21; E. Dybowska, Współczesne formy życia rodzinnego i małżeńskiego, w: Pedagogika rodziny na początku XXI wieku w świetle pojęć i terminów, red. B. Sieradzka-Baziur, Kraków 2018, s. 15. 
dotyczą cech zarówno jakościowych, jak i ilościowych ${ }^{27}$. Szczególną sytuacją, która w nagły i w związku z tym dość radykalny sposób zmieniła funkcjonowanie współczesnej rodziny, jest pandemia koronawirusa SARS-CoV-2, która wkroczyła w życie społeczne w Polsce w marcu 2020 roku i diametralnie je zmieniła. Rodzina została wystawiona na próbę, a w wielu sytuacjach - przez czynniki rodzinne i pozarodzinne naruszające homeostazę - zachwiała się stabilność systemu rodzinnego ${ }^{28}$. Należy więc pamiętać, że wsparcie rodziny w przezwyciężaniu kryzysów jest zadaniem i wyzwaniem dla specjalistów. Specjalistów, którzy pracę tę poddają superwizji.

\section{Zakończenie}

Wieloaspektowość ujęć tematyki rodziny, definiowania jej fenomenu, a także różnorodność form funkcjonowania rodzinnego jako przestrzeni wspólnego życia oznacza, że zarówno sytuacje doświadczane i przeżywane $\mathrm{w}$ rodzinie, jak i te, które mają przyczynę poza jej przestrzenią, będą miały dla rodziny podobne znaczenie ${ }^{29}$. Wszystkie one będą wpływały na jej funkcjonowanie i sprzyjały rozwojowi jej członków lub będą dla niej trudnym czy traumatycznym doświadczeniem. Mogą naruszyć funkcjonującą do tej pory homeostazę i wymusić zmiany. Rodziny znajdujące się w zasięgu troski pomocy społecznej zwykle $\mathrm{z}$ taką zmianą nie potrafiły sobie same poradzić. Osoby pracujące z rodziną, która doświadcza na tyle silnego zachwiania równowagi, iż sama nie potrafi się z nią uporać, potrzebują systematycznego wzmacniania swoich kompetencji zarówno osobowych, jak i zawodowych. Szczególną przestrzenią do tego jest superwizja, która wprowadza ład między postrzeganiem a rozumieniem rodziny. Poddanie swojej pracy temu procesowi pozwala na utrzymanie granicy w pomaganiu oraz przeciwdziałanie przeniesienia negatywnych skojarzeń wynikających z własnych doświadczeń życiowych na daną rodzinę. Superwizja to również proces ustawicznego uczenia się i doskonalenia zawodowego, a także dba-

\footnotetext{
27 R. Doniec, Socjalizacja rodzinna $w$ kontekście przemian współczesnej rodziny w Polsce, „Rocznik Pedagogiki Rodziny” (2003), t. 7, s. 151-152.

28 W. Świętochowski, Rodzina w ujęciu systemowym, dz. cyt., s. 42.

29 M. Braun-Gałkowska, Psychologia domowa, dz. cyt., s. 20.
} 
łość o przeciwdziałanie wypaleniu zawodowemu. Wielość funkcji superwizji oraz korzyści wynikających z jej zastosowania pozwalają na postawienie tezy, że w pracy z rodzinami jest ona nieodzowna.

\section{Bibliografia}

Barbaro M. de, Struktura rodziny, w: Wprowadzenie do systemowego rozumienia rodziny, red. B. de Barbaro, Kraków 1999, s. 45-55.

Błasiak A., Między (nie)obecnością a zaangażowaniem. Rodzicielstwo rekonstruowane w ponowoczesności, Kraków 2019.

Braun-Gałkowska M., Psychologia domowa, Lublin 2008.

Domaradzki P., Krzyszkowski J., Sosonowski M., Włoch A., Superwizja pracy socjalnej dla praktyków, Łódź 2016.

Doniec R., Socjalizacja rodzinna w kontekście przemian współczesnej rodziny $w$ Polsce, „Rocznik Pedagogiki Rodziny” (2003), t. 7, s. 131-148.

Dybowska E., Współczesne formy życia rodzinnego i małżeńskiego, w: Pedagogika rodziny na początku XXI wieku w świetle pojęć i terminów, red. B. Sieradzka-Baziur, Kraków 2018, s. 35-58.

Superwizja jako instrument rozwoju zawodowego $w$ służbach społecznych, red. M. Ferreira, M. Grewiński, J. Reis-Jorge, Warszawa 2014.

Superwizja pracy socjalnej, red. M. Grewiński, B. Skrzypczak, Warszawa 2014.

Jarosz E., Wysocka E., Diagnoza psychopedagogiczna: podstawowe problemy i rozwiąania, Warszawa 2006.

Kadushis A., Supervision in Social Work, New York 1976.

Krasiejko I., Asystentura rodziny. Rekomendacje metodyczne i organizacyjne, Warszawa 2016.

Krasiejko I., Rodzina z dziećmi. Rodzina dysfunkcyjna, Warszawa 2019.

Lipowicz E., Praca socjalna z rodzina. Diagnoza-projektowanie-zmiana, Zielona Góra 2014.

Margasiński A., Teoria i wybrane modele systemów rodzinnych, w: Rodzina w ujęciu systemowym. Teoria i badania, red. A. Margasiński, Warszawa 2015, s. 6-32. 
Ostoja-Zawadzka K., Cykl życia rodzinnego, w: Wprowadzenie do systemowego rozumienia rodziny, red. B. de Barbaro, Kraków 1999, s. 18-30.

Rostowska T., Borchet J., Proces parentyfikacji w kontekście teorii systemowej, „Roczniki Pedagogiczne” 44 (2016), t. 8, nr 3, s. 5-21.

Ryś M., Relacje wewnątrzrodzinne w świetle badań psychologicznych, w: $O b$ licze współczesnej rodziny polskiej, red. B. Mierzwiński, E. Dybowska, Kraków 2003, s. 29-45.

Satir V., Terapia rodziny. Teoria i praktyka, Gdańsk 2000.

Szmagalski J., Superwizja pracy socjalnej. Zastosowania i dylematy, Warszawa 2009.

Świętochowski W., Rodzina w ujęciu systemowym, w: Psychologia rodziny, red. I. Janicka, H. Liberska, Warszawa 2014, s. 21-45.

Tarnowski J., Praca z osobami i rodzinami w sytuacji kryzysowej, w: Rola pracy socjalnej w przeciwdziałaniu zjawisku wykluczenia społecznego, red. D. Błasiak, I. Piątkowska-Lipka, Katowice 2012, s. 161-171.

Ustawa z dnia 5 sierpnia 2015 r. o zmianie ustawy o pomocy społecznej (Dz. U. z 2015 r. poz. 1310).

Wysocka E., Warsztat diagnostyczny pracownika socjalnego w obszarze pracy $z$ rodzina oraz przedmiotowe $i$ podmiotowe uwarunkowania procesu diagnozy środowiska rodzinnego, w: Pomoc społeczna wobec rodzin. Interdyscyplinarne rozważania o publicznej trosce o dziecko i rodzine, red. D. Trawkowska, Toruń 2011, s. 195-225. 


\section{Specyfika wychowania w rodzinie}


